\title{
Analysis of road tax in the international context
}

\author{
Adela Poliaková, ${ }^{*}$, and Katarina Frajtová Michalíková ${ }^{1}$ \\ ${ }^{1}$ University of Zilina, Faculty of Operation and Economics of Transport and Communications, \\ Univerzitna 1, 01026 Zilina, Slovakia
}

\begin{abstract}
Research background: Reducing the costs of transport companies is a permanent and important task for the sustainability of the company's development. The operation of transport companies brings externalities, which ultimately burden the company, which creates pressure to eliminate them by those who cause them. This pressure increases costs for transport companies, so they often try to avoid responsibility for environmental pollution. The European Union supports the creation of legislative instruments that would favor transport companies that give preference to greener and more fuel-efficient vehicles when operating. However, the modernization of the vehicle fleet also brings with it increased costs for investments in fixed assets.

Purpose of the article: The aim of this article is to analyze the real tax burdens in the individual Member States and to point out that rates within the European Union are not uniform and represent a space for speculative behavior by transport operators. At the same time, it should be pointed out that the motivation of carriers to reduce transport externalities is insufficient if Member States are left a large margin of manipulation.

Methods: We obtained data on road tax rates from the laws in individual countries. We used Scania truck data to analyze the impact of rates.

Findings \& Value added: When creating the price, it is necessary to consider all costs related to the implementation of transport. One of these costs is the motor vehicle tax. This tax represents a fixed cost for the carrier, which burdens the vehicle regardless of whether the vehicle is in operation or in technical readiness. We found that the adjustment of road tax resp. motor vehicle taxes has significant shortcomings in the EU. Not only do some countries do not favor the use of clean vehicles, but tax rates also vary greatly from one Member State to another.
\end{abstract}

Keywords: road tax; tax system; motor vehicle tax

JEL Classification: $H 71 ; K 34 ; H 23$

\footnotetext{
*Corresponding author: adela.poliakova@fpedas.uniza.sk
} 


\section{Introduction}

As a rule, newer vehicles have a smaller negative ecological impact on the environment, so modernizing the vehicle fleet is in the interest of society (Konecny, 2018). The renowned Association of European Vehicle Designers (ACEA) in August last year brought unpleasant results to the analysis of the average age of vehicles for the Central European region (Fig. 1). The Slovak Republic had a worse average age of vehicles than the European average. (Poliak, 2020).

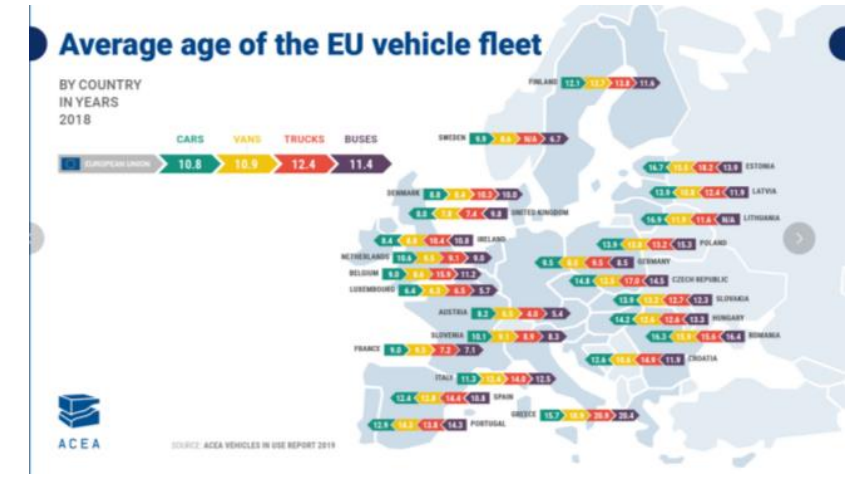

Figure 1. Average age of vehicles in EU.

Source: https://autobild.pluska.sk/novinky/tvrdy-pravdivy-graf-priemerny-vek-aut-eu-ukazuje-velkerozdiely-medzi-vychodom-zapadom (2021)

The European Union supports the reduction of the negative effects of transport on the environment and obliges the Member States to favor the operation of newer and greener vehicles (Ionescu, 2020; Poliak, 2021). When creating the price, it is necessary to consider all costs related to the implementation of transport. (Walker et al., 2020). One of these costs is the motor vehicle tax. This tax represents a fixed cost for the carrier, which burdens the vehicle regardless of whether the vehicle is in operation or in technical readiness. Motor vehicle tax is not uniform within the EU, it is regulated by Directive 1999/62 / EC. Therefore, there are differences between the principles of taxation in individual countries, but the problem is mainly the different level of the tax rate, as the directive only sets rate thresholds for motor vehicles and road trains.

\section{Analysis of road tax in EU}

\subsection{The motor vehicle tax in Slovak Republic}

According to ACEA (2019, March 09), the average age of vehicles in Slovakia in 2019 was 14 years, while the EU average was 13 years. It can be assumed that smaller carriers in particular use older vehicles of the EURO 3 emission class, the production of which ceased in 2006. Since 2015, a reduction in the tax rate for newer and greener vehicles in the Slovak Republic has been introduced. (Konecny, 2018). The reduction of the tax rate follows from Act no. 361/2014 Coll. on motor vehicle tax, in which the percentage tax relief is granted for new vehicles and, conversely, for vehicles older than 6 years, the motor vehicle tax is increased.

The subject of the tax are motor vehicles registered in the Slovak Republic, used for business or other self-employed activity of categories L, M, N and O. 
Act no. 361/2014 Coll. on motor vehicle tax provides percentage discounts for new vehicles. Table 1 contains data on the reduction or increase of the annual tax rate, where the amount of reduction resp. increases depends on the number of months since the first registration of the vehicle. These modifications apply to motorcycles, small buses, small lorries and trailers.

Table 1. Reduction and increase of the annual tax rate of categories L, M1, N1, N2, O1 to O3

\begin{tabular}{|c|c|}
\hline Number of months from the first registration & Reduction / increase of the tax rate \\
\hline $1-36$ & $-25 \%$ \\
\hline $37-72$ & $-20 \%$ \\
\hline $73-108$ & $-15 \%$ \\
\hline $109-144$ & $0 \%$ \\
\hline $145-156$ & $+10 \%$ \\
\hline 157 a viac & $+20 \%$ \\
\hline
\end{tabular}

Source: processed according to Zákon č. 361/2014 Z. z. (2021)

The tax advantage for buses and heavy goods vehicles is even more significant. The tax on new vehicles can be reduced by up to $50 \%$, as shown in Table 2 .

Table 2. Reduction and increase of the annual tax rate M2, M3 and N3

\begin{tabular}{|c|c|}
\hline Number of months from the first registration & Tax rate reduction \\
\hline $1-36$ & $-50 \%$ \\
\hline $37-72$ & $-40 \%$ \\
\hline $73-108$ & $-30 \%$ \\
\hline $109-144$ & $-20 \%$ \\
\hline $145-156$ & $-10 \%$ \\
\hline 157 and more & $0 \%$ \\
\hline
\end{tabular}

Source: processed according to Zákon č. 361/2014 Z. Z. (2021)

For heavy trailers, it is possible to get a $60 \%$ discount regardless of the age of the vehicle. Furthermore, the annual tax rate can be reduced by $50 \%$ for hybrid vehicles, hybrid electric vehicles, $\mathrm{L}, \mathrm{M}$ and $\mathrm{N}$ vehicles with $\mathrm{LPG}, \mathrm{CNG}$ or hydrogen propulsion. If the carrier proves that the vehicle has been used at least 60 times in combined transport during the tax period, it may reduce the tax rate by $50 \%$. The individual tax rates are listed in Annex 1 of the Motor Vehicle Tax Act.

\subsection{The road tax in Czech Republic}

The motor vehicle tax in the Czech Republic is set by Act 16/1993 Coll. and is among property taxes. The subject of the tax are motor vehicles and their trailers registered in the Czech Republic, which are used in the Czech Republic for business or other self-employed activities. (Poliakova, 2018). The tax also applies to vehicles with a maximum permissible weight of over 3.5 tons intended exclusively for the transport of goods and registered in the Czech Republic, regardless of whether they are used for business or private purposes. (Poliakova, 2018). Vehicles with less than four wheels, which are registered in the technical certificate as category L1, as well as vehicles of diplomatic missions and consular posts, vehicles providing regular domestic passenger transport and vehicles operated by the armed forces, are exempt from the tax. In addition to these vehicles, freight vehicles with a maximum permissible weight of less than 12 tons which are electrically propelled, hybrid or use LPG or CNG as fuel are also exempted. The tax base for passenger cars is the engine displacement in $\mathrm{cm} 3$, except for electric 
passenger cars. The annual rate for passenger cars ranges from EUR 47.41 (CZK 1,2002) to EUR 165.95 (CZK 4,200). In the case of commercial vehicles and buses, the tax base is the maximum permissible weight in tons and the number of axles. The rate ranges from EUR 71.12 (CZK 1,800) to EUR 1,493.54 (CZK 3,718,001).

The tax rate can be reduced by $48 \%$ for the next 36 calendar months from the date of its first registration, by $40 \%$ for the next 36 calendar months and by $25 \%$ for the next 36 calendar months. The right to the relevant reduction of the tax rate arises in the calendar month of the first registration of the vehicle and ends after the 108th calendar month. Furthermore, the tax rate can be reduced by $25 \%$ for vehicles used in agricultural production and by $48 \%$ for vehicles not used for business with a total weight of more than 12 tons. For vehicles registered for the first time in the Czech Republic or abroad until 31 December 1989, the tax rate is increased by $25 \%$. A taxpayer who uses vehicles for combined transport can apply for a reduction in the tax rate. The reduction depends on the number of journeys in combined transport. These journeys must be proved in the transport document with the confirmed data of the combined transport terminal or the railway station where the loading or unloading took place. For a vehicle used exclusively in the initial or final section of combined transport, the rate is reduced by $100 \%$.(www.telecom.gov.sk)

\subsection{The motor vehicle tax in Poland}

In Poland, motor vehicle tax is one of the local taxes. The subject of the tax are trucks with a maximum permissible weight over $3.5 \mathrm{t}$, tractors, semi-trailers, trailers, and buses. These vehicles must be registered in Poland. Vehicles owned by diplomatic missions, consular posts, special purpose vehicles, historic vehicles and vehicles used in agriculture are exempt from the tax. The tax is imposed on natural persons and the legal owners of means of transport, which may also be an organizational unit.

The amount of the tax rate is set by the city (municipal) council within the limits set out in the Act on Local Taxes and Fees. The law defines the upper limit and, for certain types of vehicles, the lower limit of the rate. The amount of tax depends on the type of vehicle, the total permissible weight, the number of axles and the axle suspension. The change in the rate depends on the percentage indicator of the exchange rate of the euro against the national currency on the first working day of October; if this indicator is less than $5 \%$, the tax rate will not change next year. The tax is paid in two installments, the first must be paid by February 15 and the second by September 15. (Ustawa, 2021) Because the motor vehicle tax in Poland is a local tax, the rates vary from region to region. For this reason, the minimum and maximum rates are given. The maximum motor vehicle tax rates are given in Table 3.

Table 3. Maximum rate of motor vehicle tax for 2016 in Poland

\begin{tabular}{|c|c|c|c|}
\hline Vehicle type & Weight/number of seats & Tax rate (PLN) & Tax rate (EUR) \\
\hline \multirow{4}{*}{ Truck } & over 3.5 tons up to 5.5 tons & 676.20 & 147.56 \\
\cline { 2 - 4 } & over 5.5 tons up to 9 tons & $1,028.00$ & 224.33 \\
\cline { 2 - 4 } & over 9 tons up to 12 tons & $1,233.60$ & 50.98 \\
\cline { 2 - 4 } & more than 12 tons & $2,354.12$ & 513.71 \\
\hline \multirow{2}{*}{ Tractor } & to 36 tons & $1,819.56$ & 397.06 \\
\cline { 2 - 4 } & over 36 tons & $2,354.12$ & 513.71 \\
\hline \multirow{3}{*}{ Trailer/semitrailer } & over 7 tons up to 12 tons & $1,233.60$ & 269.19 \\
\cline { 2 - 4 } & od 12 tons up to 36 tons & $1,439.20$ & 314.06 \\
\cline { 2 - 4 } & over 36 tons & $1,819.56$ & 397.06 \\
\hline
\end{tabular}

2 The exchange rate according to the NBS of 4.10.2021 is $1 \mathrm{EUR}=25.309 \mathrm{CZK}$

3 The exchange rate according to the NBS as of 4.10.2021 is $1 \mathrm{EUR}=4.5826 \mathrm{PLN}$ 


\begin{tabular}{|c|c|c|c|}
\hline \multirow{2}{*}{ Bus } & less than 22 seats & $1,918.50$ & 418.65 \\
\cline { 2 - 4 } & more than 22 seats & $2,425.51$ & 529.29 \\
\hline
\end{tabular}

Source: processed according to Ustawa (2021)

The amount of the tax rate can be reduced if the vehicle was used in combined transport. If the vehicle has performed:

- more than 20 and less than 49 rides, reduction of the tax rate by $25 \%$

- more than 50 and less than 69 rides, reduction of the tax rate by $50 \%$

- more than 70 and less than 99 rides, tax rate reduction by $75 \%$

- more than 100 , a reduction of $100 \%$ in the annual tax rate.

\subsection{The motor vehicle tax in Hungary}

The motor vehicle tax in Hungary has the character of a national tax, its revenue is used for the development and maintenance of road infrastructure. Not only commercial vehicles but also passenger cars registered in Hungary are subject to taxation, while the tax base for passenger cars is their officially registered power in $\mathrm{kW}$ and the number of years since production. In the case of commercial vehicles, the tax base is the total weight of the vehicle and emission limits. Age is not considered for these vehicles.

Table 4 shows the tax rates for both passenger cars and commercial vehicles. The rate in the case of a semi-trailer combination is determined separately for the tractor and for the semi-trailer. The tax base for trucks is their own curb weight increased by $50 \%$ of their payload. The tax base for tractors is twice their own weight, increased by half the positive difference between the maximum weight that the tractor can tow and its own weight.

Table 4. Motor vehicle tax rate in Hungary

\begin{tabular}{|l|c|c|c|}
\hline Vehicle type & $\begin{array}{c}\text { Age of vehicle } \\
\text { [years] }\end{array}$ & \multicolumn{2}{|c|}{ Tax rate } \\
\hline Passenger car & $0-3$ & $345 \mathrm{HUF}^{4} / \mathrm{kW}$ & $1.11 \mathrm{EUR} / \mathrm{kW}$ \\
\hline Passenger car & $4-7$ & $300 \mathrm{HUF} / \mathrm{kW}$ & $0.96 \mathrm{EUR} / \mathrm{kW}$ \\
\hline Passenger car & $8-11$ & $230 \mathrm{HUF} / \mathrm{kW}$ & $0.74 \mathrm{EUR} / \mathrm{kW}$ \\
\hline Passenger car & $12-15$ & $185 \mathrm{HUF} / \mathrm{kW}$ & $0.59 \mathrm{EUR} / \mathrm{kW}$ \\
\hline Passenger car & more than 16 & $140 \mathrm{HUF} / \mathrm{kW}$ & $0.45 \mathrm{EUR} / \mathrm{kW}$ \\
\hline Trucks, tractors, and buses with air springs & - & $850 \mathrm{HUF} / 100 \mathrm{~kg}$ & $2.73 \mathrm{EUR} / \mathrm{kW}$ \\
\hline $\begin{array}{l}\text { Trucks, tractors, and buses without air } \\
\text { springs }\end{array}$ & - & $1380 \mathrm{HUF} / 100 \mathrm{~kg}$ & $4.43 \mathrm{EUR} / \mathrm{kW}$ \\
\hline
\end{tabular}

Source: processed according to Ustawa o podatkach i opłatach lokalnych 2019 (2021)

\subsection{The motor vehicle tax in Austria}

Cars and commercial vehicles are subject to taxes. The tax base for motorcycles is the engine displacement in $\mathrm{cm} 3$. The monthly tax rate is 0.0275 EUR per $\mathrm{cm} 3$. In the case of motor vehicles weighing up to $3.5 \mathrm{t}$, the tax base is power in $\mathrm{kW}$. (www.bmf.gv.at)

Motor vehicles with positive-ignition engines registered before 1 January 1987 shall be subject to a $20 \%$ tax on motor vehicles if they are not fitted with a regulated catalytic converter. The monthly rates are as follows:

- for the first $24 \mathrm{~kW}$ of power, the rate is 0 EUR

- another $66 \mathrm{~kW}$ of power is the rate of 0.682 EUR

- for another $20 \mathrm{~kW}$ of power, the rate is $0.726 \mathrm{EUR}$

4 The exchange rate according to the NBS as of 5.10.2021 is $1 \mathrm{EUR}=311.47 \mathrm{HUF}$. 
- and for every $\mathrm{kW}$ over and above, the rate is EUR 0.825 , with a minimum rate of EUR 6.82 per month.

The tax base for commercial vehicles weighing more than 3.5 tons is the maximum weight. The weight is rounded to whole tons, with a minimum rate of EUR 15 and a maximum of EUR 80, with a trailer of EUR 66. Monthly tax rates are (www.bmf.gv.at):

- for motor vehicles with a maximum mass exceeding 3.5 tons but less than 12 tons, EUR 1.55 for each ton of maximum authorized mass.

- for motor vehicles with a maximum mass exceeding 12 tons but less than 18 tons, EUR 1.70 for each ton of maximum authorized mass.

- for motor vehicles with a maximum gross mass exceeding 18 tons, EUR 1,90 for each ton of maximum authorized mass.

In Austria, tractors and semi-trailers are taxed separately according to the maximum permissible weight. The minimum annual rate is EUR 180, and the maximum rate is EUR 960 for commercial vehicles over 3.5 tons, and in the case of trailers the maximum rate is EUR 792 per year. Federal vehicles, ambulances, buses, taxis, vehicles for the disabled, motorcycles with an engine capacity not exceeding $1001 \mathrm{~cm} 3$, hybrid electric vehicles, vehicles subject to bilateral agreements are exempt from the obligation to pay motor vehicle tax, and vehicles over 3.5 tons used in combined transport.

\subsection{The motor vehicle tax in Germany}

The motor vehicle tax in Germany is an environmentally friendly tax designed to promote, for example, through tax breaks for the development of new technologies that use alternative energy sources. In Germany, vehicles used for business as well as for private purposes are taxed. The tax base for motorcycles is the displacement of the engine cylinders. In the case of passenger cars, it is important for the tax base whether the vehicle was registered before or after 1 July 2009. If the vehicle was registered before that date, the tax base is the engine cylinder displacement and the emission limit data. The tax base for a vehicle registered after 1 July 2009 is the engine displacement and $\mathrm{CO} 2$ emissions. In the case of commercial vehicles with a total weight of up to $3.5 \mathrm{t}$, the tax base is the total weight in kilograms and for vehicles over $3.5 \mathrm{t}$, the tax base is the total weight in kilograms, exhaust emissions and vehicle noise. The annual tax rate, depending on the tax base, ranges from EUR 6.42 to EUR 1,681 for commercial vehicles over $3.5 \mathrm{t}$. For trailers, the tax rate is EUR 7.46 for each $2001 \mathrm{~kg}$ of total weight, but not more than EUR 373.24. (www.gesetze-im-internet.de)

Diesel passenger cars that were registered between 1 January 2011 and 31 December 2013 and meet the requirements of EURO 6 may be partially exempted from the tax rate. This exemption will end when the tax credit reaches EUR 150. This exemption can only be used once for each vehicle. Electric vehicles that were registered until 31 December 2015 are exempt from tax for a period of ten years, if they have been registered since 1 January 2016, they are exempt for a period of five years. The tax will be refunded upon written request for a period of twelve months from the beginning of the payment period if the vehicle has made more than 124 combined transport journeys during this period. If the vehicle has made less than 124 journeys, the annual tax rate can be reduced. (www.gesetze-im-internet.de)

\subsection{The motor vehicle tax in Italy}

The motor vehicle tax is a local tax levied on motorcycles and motor vehicles registered in the Italian Republic, the payment of which represents revenue for each region. The subject of the tax are therefore vehicles registered in the Public Automobile Register (PRA). The tax base for motorcycles is the engine displacement in $\mathrm{cm} 3$, in the case of cars, buses and special vehicles, the tax base is their engine power in $\mathrm{kW}$, while also considering the emission class of the 
vehicle. The lower the emission class of the vehicle, the higher the tax rate. For commercial vehicles below $12 \mathrm{t}$, the tax base is the total payload of the vehicle and above $12 \mathrm{t}$ it is the total weight, number of axles and axle suspension. The tax can be paid in several ways, but only when paying for the whole year does the taxpayer receive a 3\% tax relief. (www.miolegale.it)

In Italy, the motor vehicle tax is local in nature, which means that tax rates are not uniform in all regions of the country. Therefore, Annex 4 shows the tax rate for commercial vehicles over 12 tons in the Lombardy region, not in Italy. Certain categories of taxpayers and types of vehicles are exempt from motor vehicle tax. These include cars for the transport of disabled people, as well as vehicles powered by CNG, LPG, electric vehicles, and historic vehicles. The tax exemption or reduction varies according to the regions in which the vehicles are registered.

\subsection{The motor vehicle tax in France}

The motor vehicle tax in France is a national tax levied quarterly. The tax period runs from 1 October to 30 September. (Ndiaye, 2018). There are two types of taxes on motor vehicles, the first is the tax on company vehicles and the second the so-called corrective tax. Companies that own cars must pay a tax on company vehicles. For passenger cars registered for the first time after June 2004, the amount of the tax is determined according to the amount of CO2 emissions, the rate is set in EUR / g CO2, the rate ranges from 0 EUR to 27 EUR.

Vehicles registered after June 2004 are taxed according to engine power, where the tax rate ranges from $€ 750$ to $€ 4,500$. Hybrid vehicles that produce less than $110 \mathrm{~g} / \mathrm{km}$ of CO2 are temporarily exempted from motor vehicle tax for a period of 2 years. Electric cars are completely exempt. (www.service-public.fr)

Table 5 shows the quarterly tax rates for commercial vehicles with a gross vehicle weight of more than 12 tons. The amount of tax depends on the vehicle category, number of axles, total weight and axle suspension. The tax rate is determined for the semi-trailer set as a whole (not separately for the trailer and tractor) according to the total weight. If vehicles are used in combined transport, the tax rate can be reduced by up to $75 \%$.

Table 5. Quarterly tax rate in France

\begin{tabular}{|l|c|c|c|}
\hline \multirow{2}{*}{ Vehicle category } & \multirow{2}{*}{$\begin{array}{c}\text { Gross vehicle } \\
\text { weight (tons) }\end{array}$} & \multicolumn{2}{c|}{ Quarterly tax rate (EUR) } \\
\cline { 3 - 4 } & & Pneumatic suspension & $\begin{array}{c}\text { Another suspension } \\
\text { system }\end{array}$ \\
\hline I. Motor vehicle & $>12$ & 31 & 69 \\
\hline with two axles & $>12$ & 56 & 87 \\
\hline with three axles & $12-27$ & 37 & 57 \\
\hline \multirow{2}{*}{ four and more axles } & $>27$ & 91 & 135 \\
\cline { 2 - 4 } & & & 8 \\
\hline II. Semi-trailer set & $12-20$ & 4 & 77 \\
\hline \multirow{2}{*}{ with one axle } & $>20$ & 44 & 43 \\
\hline \multirow{4}{*}{ with two axles } & $12-27$ & 29 & 117 \\
\cline { 2 - 4 } & $27-33$ & 84 & 177 \\
\cline { 2 - 4 } & $33-39$ & 117 & 233 \\
\cline { 2 - 4 } & $>39$ & 157 & 129 \\
\hline \multirow{2}{*}{$\begin{array}{l}\text { with three and more } \\
\text { axles }\end{array}$} & $12-38$ & 93 & 175 \\
\hline III. Trailers & $>38$ & 129 & 30 \\
\hline
\end{tabular}

Source: processed according to www.service-public.fr (2021) 


\section{EU Requirement}

It is clear from the above analysis that the conditions under which the motor vehicle tax is applied vary considerably across Europe.

Directive 1999/62 / EC of the European Parliament and of the Council on the charging of heavy goods vehicles for the use of certain infrastructures, which is the basic legislation on motor vehicle taxes, states that the introduction of fair mechanisms for charging carriers for infrastructure use is a tool to eliminate distortions of competition between transport undertakings of the Member States, which requires the harmonization of charging systems. In the light of the above analysis, it can be stated that even more than 20 years after its adoption, the harmonization cannot be considered complete. Within the European Union, there are significant differences between the requirements of national and international legislation. Annex 1 to that Directive sets out the minimum rates of tax applicable to vehicles.

The maximum amounts of user charges are set out in Annex II to that Directive. It should be noted that all Member States respect the tax ceiling thus set.

\section{Results and discussion}

Based on the above analysis, it is possible to recalculate the comparison of tax rates in individual countries. As a model situation, we will consider a model semi-trailer set, manufactured in 2015. It consists of a tractor with two axles, with a maximum permissible weight per axle of $19,000 \mathrm{~kg}$ and a semi-trailer with three axles with a maximum permissible weight per axle of $24,000 \mathrm{~kg}$. The curb weight of the tractor according to the registration certificate is $7,020 \mathrm{~kg}$ and the semi-trailer has a curb weight of $7,200 \mathrm{~kg}$. The semi-trailer set has a maximum total weight of $40 \mathrm{t}$. The considered semi-trailer set meets the EURO6 emission limits.

Figure 2 shows the percentage expression of the tax rate of individual countries against the Slovak Republic. The percentage difference between the minimum rate set by the European Directive 1999/62/EC and the Slovak Republic is about 58\%.

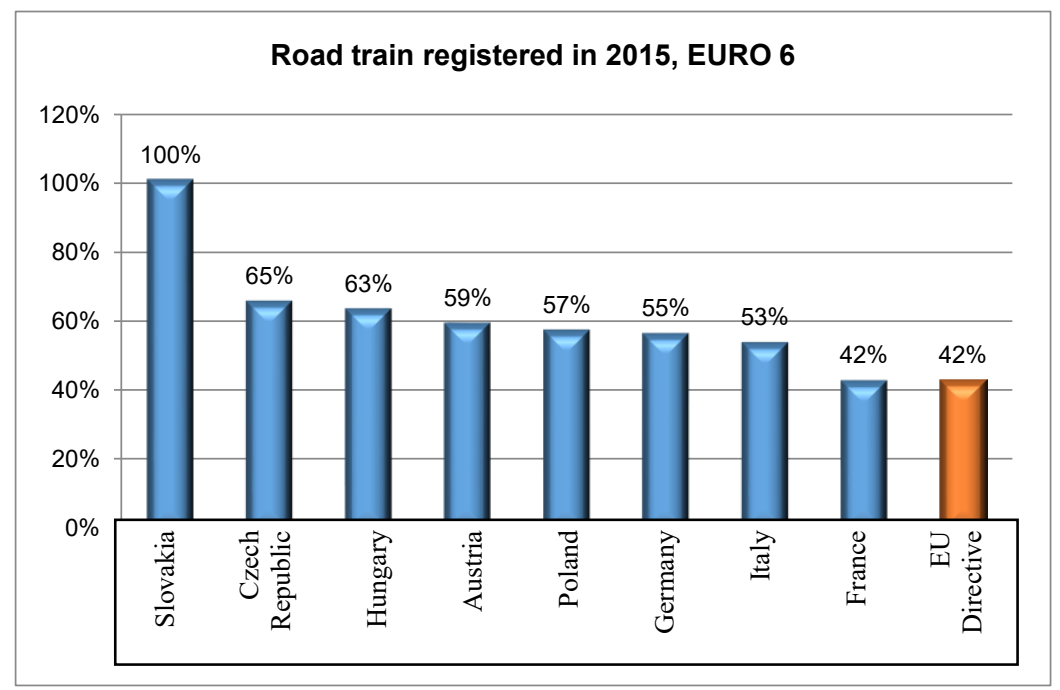

Figure 2. Percentage expression of the tax rate for EURO 6 road train against the rate in the Slovak Republic. 


\section{Conclusions}

The tax is not harmonized within the EU, but is only regulated by Directive 1999/62 / EC. However, this directive sets minimum tax rates, which is a major disadvantage, as individual countries set a much higher tax rate than that set by this directive. The maximum amounts set out in this Directive are set relatively "generously" and give Member States a large margin of maneuver.

Another problem is the subject of the tax. In some countries, only vehicles used for business are taxed, e.g., in the Slovak Republic, in other vehicles used for private purposes are also taxed. Motor vehicle tax rates are not uniform in the EU, despite a guideline adopted as early as 1999. We therefore consider it appropriate to draw attention to this shortcoming, which, despite the declared commitment to fair charging for users, creates scope for speculative behavior by transport operators who provide transport services throughout Europe. We found that the adjustments of road tax resp. motor vehicle taxes have significant shortcomings in the EU. Not only do some countries do not favor the use of clean vehicles, but tax rates also vary greatly from one Member State to another.

\section{Acknowledgements}

The paper was processed within the solution and with the support of the project VEGA 1/0121/20: Research of transfer pricing system as a tool to measure the performance of national and multinational companies in the context of earnings management in conditions of the Slovak Republic and V4 countries.

\section{References}

1. Bjertnaes, G. H. M. (2019). Efficient Combination of taxes on fuel and Vehicles. Energy Journal, 40(1), 387-408.

2. Duncan, D., Li, D. Y., \& Graham, J. D. (2020). Tax rate design and support for mileage userfees. Transport Policy, 93(1), 17-26.

3. Ionescu, L. (2020). The Economics of the Carbon Tax: Environmental Performance, Sustainable Energy, and Green Financial Behavior. Geopolitics, History, and International Relations, 12(1), 101-107.

4. Konecný, V., Semanova, S., Gnap, J., \& Stopka, O. (2018). Taxes and Charges in Road Freight Transport - a Comparative Study of theLevel of Taxes and Charges in the Slovak Republic and the Selected EU Countries. Nase More, 65(4), 208-212.

5. Ndiaye, Y. (2018). Road tax interactions among local governments: a spatial panel data analysis of the French case over the period 1984-2000. Applied Economics, 50(38), 41824196.

6. Poliak, M., Baker, A., Konecny, V., \& Nica, E. (2020). Regulatory and Governance Mechanisms for Self-Driving Cars: Social Equity Benefits and Machine Learning-based Ethical Judgments. Contemporary Readings in Law and Social Justice, 12(1), 58-64.

7. Poliak, M., Svabova, L., Konecny, V., Zhuravleva, N. A., \& Culik, K. (2021). New paradigms of quantification of economic efficiency in the transport sector. Oeconomia Copernicana, 12(1), 193-212. doi: 10.24136/oc.2021.008

8. Poliakova, A. (2018). The International Tax Treatment Is Not Sufficient - An Example of Road Tax Relief in the Slovak Republic. Proceedings of the 18th International Scientific Conference on Globalization and Its Socio-Economic Consequences. Rajecke Teplice, Slovakia, 1771-1778. 
9. Poliakova, A. (2018). What is the impact of road tax collection on the accident status due to the fault of the road? Proceedings of XI International Science-Technical Conference Automotive Safety, IEEE, USA, 1-5.

10. Poliakova, A., \& Poliak, M. (2017). The Motor vehicle Taxes and Influence on Fleet Modernization in Slovakia. Proceedings of 8th International Scientific Conference on Finance and Performance of Firms in Science, Education and Practice, Tomas Bata Univesity Zlin, Czech Republic, 913-925.

11. Santos, G. (2017). Road fuel taxes in Europe: Do they internalize road transport externalities? Transport Policy, 53(1), 120-134.

12. Walker, A., Rowland, Z., Frajtova Michalikova, K., \& Svabova, L. (2020). Urban Mobility Technologies, Algorithm-driven Sensing Devices, and Machine Learning-based Ethical Judgments in a Connected Vehicle Environment. Contemporary Readings in Law and Social Justice, 12(2), 34-42.

13. Zinca, D., \& Negrean, VA. (2018). Development of a Road Tax Payment Application using the Ethereum Platform. 13th International symposium on Electronics and Telecommunications (ISETC), IEEE, USA, 211-214.

14. Zákon č. 361/2014 Z. z. Zákon o dani z motorových vozidiel a o zmene a doplnení niektorých zákonov. (2021, October, 1st). Retrieved from: http://www.zakonypreludi.sk/zz/2014-361

15. http://www.telecom.gov.sk/externe/legeu/99-0062kon.pdf

16. Ustawa o podatkach i opłatach lokalnych 2019 (Dz.U. 2018, poz. 1445) (2021, October, 1st). Retrieved from : http://aktyprawne.poznajpodatki.pl/inne-ustawy/ustawa-o-o-podatkach-ioplatach-lokalnych-2014-dz-u-2010-nr-95-poz-613-wersja-aktualizowana/4/

17. évi LXXXII. Törvény a gépjárműadóról (1991). Retrieved from : http://net.jogtar.hu/jr/gen/hjegy_doc.cgi?docid=99100082.TV

18. https://www.bmf.gv.at/steuern/fahrzeuge/kraftfahrzeugsteuer.html

19. http://www.gesetze-im-internet.de/kraftstg/

20. http://www.miolegale.it/norme/legge-39-1953-testo-unico-tasse-automobilistiche/

21. https://www.service-public.fr/professionnels-entreprises/vosdroits/F32831 